\title{
Phytoremediation of heavy metals using acacia mangium in rahman hydraulic tin (RHT) tailings, Klian Intan, Malaysia
}

\section{Introduction}

Malaysia was once a renowned in the tin mining sector and formed the backbone of the country's economy. Due to over exploitation to feed the growing steel industry, most of the resources have been exhausted and these areas are left abandoned. Some suggest planting agricultural crops on these lands but a major concern is the presence of large amounts of heavy metals that are potentially toxic such as cadmium $(\mathrm{Cd})$, lead $(\mathrm{Pb})$ and arsenic $(\mathrm{As}){ }^{1}$ which are detrimental to human health when occurs beyond permissible amounts. ${ }^{2}$ A more feasible option would be to establish forest stands including Acacia mangium mainly because of its notable track record as a Phytoremediation. The Acacias have the potential to rehabilitate the soil through absorption and storage of heavy metals in its leaves, shoots and roots. ${ }^{3}$ and even used in treating sewage sludge soil to absorb large amounts of zinc $(\mathrm{Zn}), \mathrm{Pb}$, copper $(\mathrm{Cu}), \mathrm{Cd}$ and chromium $(\mathrm{Cr}) .{ }^{4}$ Phytoremediation is a process that utilizes plants to filter and remove contaminants through biological, physical and chemical activities initiated by the plant. Phytoremediators act as filters by first absorbing contaminants, degrading them and stabilizing the concentrations of contaminants in soil through plant uptake. This study was initiated to determine the amount of heavy metal uptake and translocation to harvestable parts as well as to quantify the concentration of heavy metal before and after planting Acacias.

\section{Methodology}

The study was conducted in Rahman Hydraulic Tin Sdn. Bhd. in the vicinity of Klian Intan, Perak, Malaysia, situated between latitudes $05^{\circ} 25^{\prime} \mathrm{N}$ and longitudes $101^{\circ} 8^{\prime} \mathrm{E}$. This area was previously mined for tin since the 1920s. The adjacent areas are surrounded by ex-tin mining ponds with large amount of tin wastes which consists of mud, liquid, sand, silt and sand. The planting area was limed and added with top soil as part of the rehabilitation program. Approximately 4 ha were planted with Acacia mangium on December 2012 spaced at $2 \mathrm{~m} \times 2 \mathrm{~m}$ and $4 \mathrm{~m}$ x 4m. In December 2016, three Acacia trees were selected for sampling with diameter at breast height (DBH) and total height being taken prior to felling. The logs were cut into different lengths namely $0.3 \mathrm{~m}, 1.3 \mathrm{~m}$ and $7.3 \mathrm{~m}$ (Figure 1 ). The fresh weights of the leaves were weighed whole and 3 replicates were taken from each tree amounting to $200 \mathrm{~g}$. The roots from each tree was excavated and sorted into big roots and small roots for biomass determination. The fresh weights of roots were weighed whole and three replications amounting to $1 \mathrm{~kg}$ were taken as samples. Tree branches were also measured and determined in a similar manner. Soil samples were collected in triplicates at a depth of $0-65 \mathrm{~cm}, 65-80 \mathrm{~cm}$ and $80-100 \mathrm{~cm}$. Soil samples and tree samples were also taken from Bukit Hari, FRIM Selangor which served as the control. Leaves, roots and shoots from both sites were retrieved and taken to the laboratory for further analysis. Soil samples were air dried and ground in a Wiley mill and then sieved using a $1 \mathrm{~mm}$ and $2 \mathrm{~mm}$ sieve. The tissue samples were oven dried at $70^{\circ} \mathrm{C}$ and ground with Wiley mill ( $1 \mathrm{~mm}$ sieved). The soil samples were digested using Aqua-regia method $^{5}$ for extraction
Volume 8 Issue 3 - 2018

\author{
Ahmad Zuhaidi Y,V Jeyanny \\ Forest Research Institute Malaysia
}

Correspondence: Ahmad Zuhaidi Y, Forest Research Institute, 52109, Kepong Selangor, Malaysia, Email zuhaidi@frim.gov.my

Received: March 07, 2018| Published: May 222018

of heavy metals. Heavy metals in plant tissues were extracted using nitric acid and hydrogen peroxide by the microwave digestion method. The concentrations of heavy metals in the plant and soil extracts were then analyzed using the Varian 725 Inductive Couple Plasma Optical Emission Spectrometer (ICP-OES).

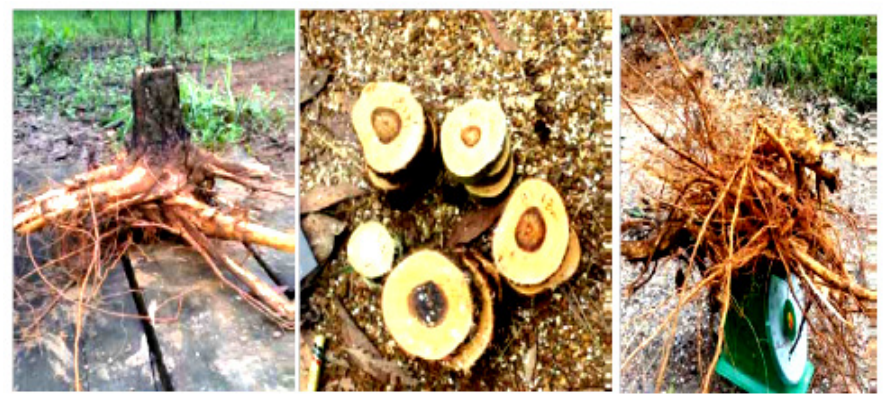

Figure I Sampling process, destructive sampling of trees, cross sectional disc samples and lateral roots of A. mangium roots from RHT plot and weighing of roots for biomass determination.

\section{Results and discussion}

The Aluminium $(\mathrm{Al})$ concentration recorded in soils under tin tailings ranged from $0.86-6.14 \%$ whereby concentrations decrease with depth and are much lower than values obtained for the control (Bukit Hari) which may implicate that Acacias were successful in absorbing $\mathrm{Al}$ (Table 1). Based on past reports, the $\mathrm{pH}$ of soil in tin tailings were very acidic and ranged from $2.4-3.3 .{ }^{6}$ When $\mathrm{pH}$ is less than 5.5, Al tends to accumulate resulting in a condition known as Al toxicity, restricting root growth. ${ }^{7}$ The phenomena of root restriction were seen in terms of biomass whereby the RHT plot recorded a much lower biomass compared with the control plot. The low levels of Al recorded in the leaves of RHT could be also due to $\mathrm{Al}$ ion translocated very slowly to upper parts of plants (Table 2). ${ }^{8}$ However, Al concentration in wood discs were quite notable in the range of $24-53 \mathrm{mg} / \mathrm{kg}$ which indicate that woody components were more efficient in storing $\mathrm{Al}$ compared to leaves and roots (Table 2). In iron $(\mathrm{Fe})$, the concentration in soil ranged from $1-6 \%$ which is 
slightly higher than observed in the control while the concentrations in leaves and roots were 200 and $1,500-2,800 \mathrm{mg} / \mathrm{kg}$, respectively (Table 1) (Table 2). High concentrations of Fe at the Rhizosphere region compared with the leaves are due to the creation of iron plaque (Fe2O3), hindering excessive amount of $\mathrm{Fe}$ entering the plant tissue. ${ }^{9}$ Thus, relatively lower levels of Fe were observed in leaves (Table 2) and wood disc samples (Table 3). Phytoremediation methods, particularly phytoextraction, have been used on a variety of metal contaminants including $\mathrm{Fe}^{10}$ and works on the basis of transporting and accumulating large quantities of metals from the soil into harvestable parts of roots and aboveground shoot. According to the results, $\mathrm{Cu}$ in soil ranged from $50-79 \mathrm{mg} / \mathrm{kg}$ which was more than 70 times higher than the control (Table 1). Copper values were low in tissue, wood and roots thus confirming that A.mangium was able to absorb $\mathrm{Cu}$ in lesser quantities only. Similarly, the values for $\mathrm{Pb}$ were $30-330 \mathrm{mg} / \mathrm{kg}$ in soil and increased with depths and were higher than control.

Table I Soil analysis results from Bukit Hari (CON) and RHT (TRT) area

\section{Soil}

depth Heavy metal

(c) concentrations

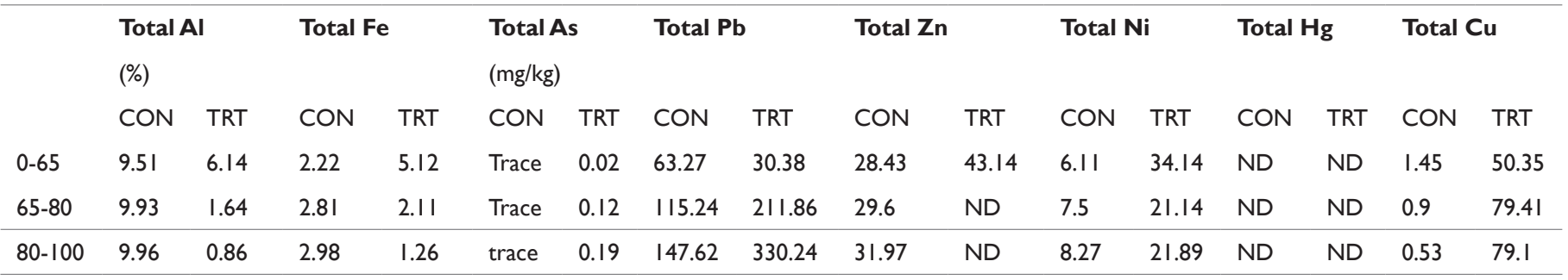

Table 2 Tissue analysis results from Bukit Hari (CON) and RHT (TRT) area

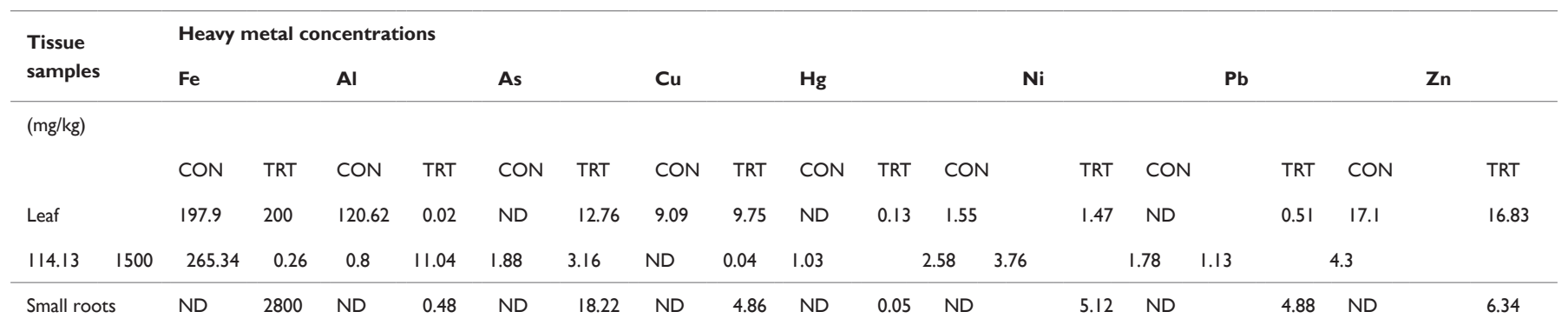

Table 3 Wood disc cross sections results from Bukit Hari (CON) and RHT (TRT) area

\begin{tabular}{|c|c|c|c|c|c|c|c|c|c|c|c|c|c|c|c|c|}
\hline \multirow{3}{*}{$\begin{array}{l}\text { Wood disc } \\
\text { (m) }\end{array}$} & \multicolumn{16}{|c|}{ Heavy metal concentrations } \\
\hline & \multicolumn{2}{|l|}{$\begin{array}{l}\mathrm{Fe} \\
(\mathrm{mg} / \\
\mathrm{kg})\end{array}$} & \multicolumn{2}{|l|}{ Al } & \multicolumn{2}{|l|}{ As } & \multicolumn{2}{|l|}{$\mathrm{Cu}$} & \multicolumn{2}{|l|}{$\mathbf{H g}$} & \multicolumn{2}{|l|}{$\mathbf{N i}$} & \multicolumn{2}{|l|}{$\mathbf{P b}$} & \multicolumn{2}{|l|}{$\mathbf{Z n}$} \\
\hline & $\mathrm{CON}$ & TRT & $\mathrm{CON}$ & TRT & $\mathrm{CON}$ & TRT & $\mathrm{CON}$ & TRT & $\mathrm{CON}$ & TRT & $\mathrm{CON}$ & TRT & $\mathrm{CON}$ & TRT & $\mathrm{CON}$ & TRT \\
\hline 0.3 & 83.04 & 76.64 & 71.23 & 52.42 & 4.02 & ND & 1.04 & 1.08 & ND & ND & 1.25 & 0.69 & ND & 0.45 & 3.13 & ND \\
\hline 1.3 & 83.09 & 58.65 & 36.1 & 24.53 & ND & 1.18 & 0.75 & 1.19 & ND & ND & 0.63 & 0.91 & ND & 2.28 & 7.79 & 3.52 \\
\hline 7.3 & 22.24 & I 32.79 & 26.46 & 53.14 & I.I & 1.22 & 0.2 & 1.88 & ND & ND & 0.59 & 0.77 & 1.22 & 0.73 & 2.4 & 28.94 \\
\hline
\end{tabular}

ND, Not Detected; CON, Control;TRT, Treatment

Values for tissue samples overall were less than $5 \mathrm{mg} / \mathrm{kg}$ as most of the $\mathrm{Pb}$ were translocated to the roots compared with the discs and leave samples. It was seen here that A. mangium was not able to sequester $\mathrm{Pb}$ in high quantities thus classified as a low phytoremediator. We believe that $\mathrm{Pb}$ was less mobile in soil as it may have bind strongly with oxides of $\mathrm{Fe}$, manganese $(\mathrm{Mn})$ and $\mathrm{Al} .{ }^{11}$ The concentration of zinc $(\mathrm{Zn})$ in the soil was $43 \mathrm{mg} / \mathrm{kg}$ in the $0-65 \mathrm{~cm}$ profile. This was not detrimental to trees. Both tissues samples of discs and roots showed values less than $10 \mathrm{mg} / \mathrm{kg}$. Leaves were on the higher side at $17 \mathrm{mg} / \mathrm{kg}$ comparable to control (Table 2) but still within a normal range for tissue samples. Zinc was translocated to leaves compared with other parts of the trees which show a good example of moderate Phytoremediation of A. mangium trees. Nickel (Ni) values were
20-35 mg/kg in soil (permissible level) and less than $1.5 \mathrm{mg} / \mathrm{kg}$ in discs and leaves similar to control (Table 1) (Table 2). Roots showed $5 \mathrm{ppm}$ had the highest amount among other tissue samples. Mercury $(\mathrm{Hg})$ levels were somewhat absent in soil and tissue samples were traces in the sand tailings. Overall, Arsenic (As) in soil was less than $1 \mathrm{ppm}$ but the values increased with increasing depths (Table 1). Thus, the small roots showed levels more than $12 \mathrm{mg} / \mathrm{kg}$ which can be classified as a very good Phytoremediation at more than $80 \mathrm{~cm}$ depth. Arsenic is readily absorbed by iron oxides and oxyhydroxides at low or neutral $\mathrm{pH}^{12}$ reducing its mobility. Thus, in low $\mathrm{pH}$ conditions where Fe hydroxides are present, mobility and bioavailability of As is reduced. ${ }^{13}$ 


\section{Conclusion}

We may conclude that $\mathrm{A}$. mangium absorbed best both $\mathrm{Al}$ and $\mathrm{Fe}$ compared with other elements. Zinc and As were moderately absorbed by A. mangium in the tin tailings. Other elements were poorly absorbed or were in trace concentrations and negligible. It is advised that tin tailings such as in the RHT area is afforested with Acacia mangium. This is because Acacia mangium is an important species for Phytoremediation, and its ability to have high bio concentration factor (BCF) and conducive for heavy metal translocation. Overall, of forestation of ex-mining sites should be actively promoted as it creates new value in terms economy and ecology. These areas can also be used for development of new forests and as potential sites for alternative crops.

\section{Acknowledgements}

The authors would like to express their gratitude to Rahman Hydraulic Tin Sdn Bhd for financial assistance through the work carried out and the supporting staffs of Forest Plantation Programme, FRIM for field assistance.

\section{Conflict of interest}

The authors declared there is no conflict of interest.

\section{References}

1. Ang LH, HO Wm, Ramli MO, et al. The update of potentially toxic elements in some economically important plants and fish produced from ex-mining sites in Bidor, Perak. In Proceedings of the Malaysian Science Technology Convention. 2000; 18-20 September; 2000; Kota Kinabalu; Malaysia.

2. Ang LH, Tang LK, HO Wm, et al. Phytoremediation of $\mathrm{Cd}$ and $\mathrm{Pb}$ by four tropical timber species grown on an ex-tin mine in Peninsular Malaysia. International Journal of Environmental Chemical Ecological Geological \& Geophysical Engineering. 2010;4(2):70-74.

3. Veronica J, Majid NM, Islam MM, et al. Assessment of heavy metal uptake and translocation in Acacia mangium for phytoremediation of cadmium contaminated soil. Journal of Food Agriculture and Environment. 2011;9:588-592.
4. Nik MM, Islam MM, Mathew L. Heavy metal uptake and translocation by mangium (Acacia mangium) from sewage sludge contaminated soil. Australian Journal of Crop Science. 2012;6(8):1228-1235.

5. EPA-ROC. The Standard Methods for Determination of Heavy Metals in Soils and Plants, National Institute of Environmental Analysis of EPAROC, Taipei (In Chinese); 1994.

6. Suhaimi WC, Mohamad Fakhri I, Wan Rasidah K. Soil suitability assessment for reforestation on degraded soils. Soil survey report produced for Rahman Hydraulic Tin Sdn Bhd. 2015; 24 p.

7. Mossor Pieraszewska T, Kwit M, Eegiewicz M. The influence of aluminium ions on activity changes of some dehydrogenases and aminotransferases in yellow lupine. Biological Bulletin of Poznañ 1997;34:47-48.

8. Ma JF, Zheng SJ, Matsumoto H, et al. Detoxifying aluminum with buckwheat. Nature. 1997;390:569-570.

9. Harahap SM, Ghulamahdi M, Aziz SA, et al. Endurance Test of Three Paddy Genotypes to Different Iron Toxicity Level. Journal of Agronomy. 2014;13(3):110-116.

10. Ebbs SD, Lasat MM, Brady DJ, et al. Heavy metals in the environment: Phyto extraction of cadmium and zinc from a contaminated soil. Journal of Environmental Quality. 1997;26(5):1424-1430.

11. Angelova VR, Ivanova RV, Todorov JM, et al. Lead, Cadmium, Zinc, and Copper Bioavailability in the Soil-Plant-Animal System in a Polluted Area. ScientificWorldJournal. 2000;10:273-285.

12. Smedley PL, Kinniburgh DG. A review of the source, behaviour and distribution of arsenic in natural waters. Applied Geochemistry. 2002;17(5):517-568.

13. Alderton, David HM, Serafimovski, et al. Distribution and Mobility of Arsenic and Antimony at mine sites in FYR Macedonia. Carpathian Journal of Earth and Environmental Sciences. 2014;9(1):43-56. 